\title{
Assessment of Radiosensitivity and Biomonitoring of Exposure to Space Radiation
}

\author{
Roel Quintens, Sarah Baatout, and Marjan Moreels
}

\subsection{Individual Radiosensitivity}

Currently, the use of the terms radiation sensitivity and susceptibility is being debated (Foray et al. 2016; Wojcik et al. 2018). Some authors argue that radiation sensitivity should only be used for tissue reactions following cell death, while radiation susceptibility is the proneness to develop radiation-induced cancer (Foray et al. 2016). In the remainder of this chapter, we will use the term radiosensitivity for both cases.

It is well known from clinical practice as well as from radiobiological and toxicological experiments with high doses that each person reacts differently to radiation and drugs. The International Commission on Radiological Protection has estimated that between $5 \%$ and $15 \%$ of the population may be carriers of genetic mutations conferring them more radiosensitive (ICRP 2007). For manned spaceflight, and especially that beyond Low Earth Orbit, the individual biological responses to cosmic ray exposure may therefore be of critical concern for health-risk assessment of astronauts.

Interindividual differences in radiosensitivity have been reported with an increased incidence of both deterministic (e.g., tissue reactions like erythema or fibrosis) and stochastic effects (e.g., cancer, see also Chap. 20). Several studies demonstrated that the occurrence and severity of normal tissue reactions in response to ionizing radiation are influenced mainly by genetic susceptibility. In this context, variations in radiosensitivity between individuals may be a consequence of deficiencies in DNA repair capacity. This can be caused by specific mutations or polymorphisms in DNA repair genes such as ataxia telangiectasia mutated (ATM) (Taylor et al. 1975) or nibrin ( $N B N$ or $N B S 1)$, which is mutated in Nijmegen Breakage Syndrome (Chistiakov et al. 2008; Varon et al. 1998). They can also result from a

R. Quintens $(\bowtie) \cdot S$. Baatout $\cdot$ M. Moreels

Radiobiology Unit, Belgian Nuclear Research Centre, SCK $•$ CEN, Mol, Belgium

e-mail: roel.quintens@ sckcen.be 
combination of small variations in multiple genes (Andreassen 2005), such as those functioning in specific DNA double-strand break (DSB) repair pathways including poly (ADP-ribose) polymerase $(P A R P)$, DNA-dependent protein kinase, catalytic subunit (PRKDC), TP53, or ATM and Rad3-related (ATR).

For a radiation-related health-risk assessment for astronauts, methods that can measure and/or predict individual radiosensitivity would be of great value. In the future such assays could be used as predictive tests to identify astronauts with a greater than average risk of developing radiation-induced health effects. Moreover, the identification of (predictive) biomarkers of radiation sensitivity could also be relevant for cancer patients treated with radiotherapy. With the growing interest in personalized medicine treament plans could be better tailored to the individual patients based on their personal radiation sensitivity.

\subsection{Tools to Evaluate Radiosensitivity and Exposure Dose}

Currently, a number of tests have been described and used to assess responses to radiation. In this light, peripheral blood lymphocytes are the preferred target for assessing radiosensitivity, as they are among the most radiosensitive cell types in humans (Venkatesulu et al. 2018). Biological endpoints such as chromosomal aberrations (e.g., dicentrics, translocations, micronuclei, DNA fragmentation) and the repair capacity of radiation-induced damage have been used to determine individual radiosensitivity in vitro. These methods mostly rely on previous observations that the occurrence of chromosomal aberrations is associated with increased radiosensitivity. Furthermore, novel methods such as gene expression profiles both at the mRNA and protein level, as well as epigenetic changes may be suitable as radiation sensitivity biomarkers. Besides this, these same methods can also be used as biodosimeters, i.e., as biological measurements to predict the dose to which an individual has been exposed.

Thus, different methods can be used for the detection of radiation-induced damage or biological effects and their choice depends on several parameters (exposure duration, estimated absorbed dose, type of exposure, and time since exposure). Importantly, most of these methods can be used for rather low doses from about 0.1 or $0.2 \mathrm{~Sv}$ and upward, which is within the range of what would be encountered by astronauts on interplanetary missions. Other important advantages of using biological markers for assessing radiation exposure over physical dosimeters are that they take into account shielding by the body itself, and that they are sensitive to all types of radiation, including neutrons.

\subsubsection{Chromosomal Aberrations: Dicentrics and Stable Translocations}

The use of cytogenetic tests to monitor the occurrence of chromosomal aberrations induced by ionizing radiation dates back to the 1960s when Tough et al. described chromosomal aberrations in the blood of patients who had undergone radiotherapy 
to treat ankylosing spondylitis (Tough et al. 1960). To date, chromosomal aberrations have been widely accepted as biomarkers of exposure to ionizing radiation. Moreover, the frequency of radiation-induced chromosomal aberrations is associated with overall cancer risk (Distel et al. 2006; Tucker 2008) suggesting that they may also be used as indicators for individual radiosensitivity.

Two of the most used cytogenetics assays are the Dicentric Chromosome Assay (DCA) and fluorescent in situ hybridisation (FISH) for the analysis of stable chromosomal translocations. The DCA usually uses metaphase spreads of lymphocytes to score for chromosomes with two centromeres. Advantages of the DCA are the low background, high specificity to radiation, low interindividual variability, and high correlation between in vitro and in vivo dose estimations (Hall et al. 2017). Their half-life is between 6 months to a year, which makes them suitable for retrospective analysis after most ISS missions, but not for long-duration missions spanning several years.

Chromosomal translocations refer to the occurrence of chromosome breakage, followed by transfer of the broken-off portion, often to a different chromosome. They are usually induced by the formation of DNA DSBs and subsequent interaction of different DSBs with each other. The scoring of chromosomal translocations is mostly performed using FISH painting which uses fluorescently labeled DNA probes to mark specific regions in the DNA after which they can be visualized using fluorescence microscopy. Translocations are in general very stable, with a half-life of 6-12 years (Durante 2005) and can be transmitted by mitosis making them very suitable for retrospective biodosimetry (Awa 1997). However, the analysis of chromosomal translocations is also useful in susceptibility studies to identify genetic polymorphisms of genes involved in the individual response to ionizing radiation (Rodrigues et al. 2005) and cancer. Currently, chromosomal translocations are used in the clinic as biomarkers for cancer risk and they have been validated as intermediate endpoints of cancer. This shows the potential of using chromosomal translocations as biomarkers for radiation sensitivity as well. One of the disadvantages of using FISH compared to the DCA is the rather large interindividual variability of chromosomal translocations. However, since it is easy to obtain preexposure (i.e. pre-flight) samples from astronauts to calculate their individual background levels, this is not really a concern (Beaton-Green et al. 2015).

The use of cytogenetics assays to assess radiation effects in astronauts during spaceflight, have been applied since the late 1990's (Durante et al. 2003; Fedorenko et al. 2001; George et al. 2004, 2001; Obe et al. 1997; Testard et al. 1996; Yang et al. 1997). In general, these studies and more recent ones (Beaton-Green et al. 2015; Cucinotta et al. 2008; George et al. 2010, 2013) have shown that the number of chromosomal aberrations significantly increased during the mission, although there were large interindividual differences, which could not be attributed to the measured dose. This variability could be a consequence of differences in radiation sensitivity, but the experimental uncertainties were so high that the result could also be explained by statistical fluctuations (Durante 2005) because the doses to which the astronauts were exposed were close to the sensitivity thresholds of the assays (Cologne et al. 1998). It may therefore be anticipated that these methods would have better sensitivity 
in the case of missions of longer duration, when astronauts are exposed to higher dose equivalents. In this respect, it was shown that the occurrence of translocations increased in astronauts after repeated missions (George et al. 2013).

\subsubsection{Micronuclei}

The cytokinesis-blocked micronucleus (CBMN) assay is one of the most commonly used methods for the measurement of chromosome loss and breakage in nucleated cells (Fenech 2010). Micronuclei are small nuclear membrane-bound structures. They originate from acentric chromosome fragments or complete chromosomes which are unable to attach to the mitotic spindle during cytokinesis, thereby resulting in exclusion from the daughter nuclei into the cytoplasm. Since micronuclei are present in cells that have completed nuclear division, they are ideally scored in the binucleated stage of the cell cycle. To distinguish between nondividing cells and cells undergoing mitosis, cytochalasin-B, an inhibitor of the mitotic spindle that prevents cytokinesis, is added to the cell cultures. As a consequence, cells that have completed one nuclear division can be identified by their binucleated appearance. This leads to cells which contain two nuclei and one or more micronuclei if chromosome breaks have occurred or the centromere is damaged (Fenech and Morley 1985). New methods of detection, using high resolution in combination with flow cytometry may significantly enhance the usefulness of this assay by facilitating automation and quantification of the assay (Rodrigues et al. 2018).

Currently, the CBMN assay is being used successfully for biodosimetry after occupational, medical and accidental radiation exposure, although it is only useful after exposures above 200-300 mGy (Feng et al. 2015; Liu et al. 2009; Thierens et al. 2014; Vral et al. 2011). Furthermore, since radiosensitive cells are more susceptible to radiation-induced micronucleus formation and because micronuclei originate from mis-repair or DSBs in DNA, the CBMN assay can be used to to assess individual in vitro radiosensitivity or cancer susceptibility (Vral et al. 2011). However, the CBMN assay seems less suitable for the assessment of exposure to energetic heavy ions (Wu et al. 2006), one of the major components of cosmic radiation, especially in terms of expected health effects.

\subsubsection{Premature Chromosome Condensation (PCC) Assay}

The problems that arise with the study of metaphases (e.g., radiation-induced mitotic delay) can be circumvented by directly studying interphase cell aberrations. The PCC assay is very powerful for detecting chromatin damage in G1 or G2-phase cells and it has the advantage of being used to compare responses to different radiation types such as heavy ions or X-rays (Suzuki et al. 2006). This is in contrast to chromosome aberrations in metaphase spreads, which are not always comparable 
when cells are exposed to different types of radiation. The PCC method is especially suitable for studying radiation-induced chromatid breaks in the G2-phase, which is the cell cycle phase in which cells are the most radiosensitive (Wang et al. 2006). Therefore, the frequencies of aberrations as determined via PCC are higher than those of metaphase spreads, indicating increased sensitivity. Another advantage of the PCC method is that it can be used for dosimetry purposes, within a very high range of doses (from $200 \mathrm{mGy}$ to $\sim 20 \mathrm{~Gy}$ ) depending on the specific application (Pernot et al. 2012).

PCC occurs when mitotic cells, containing condensed chromosomes, fuse with interphase cells causing the interphase cells to produce condensed chromosomes prematurely. Although the initial protocol was very laborious and did not hold much promise to become a widely used method, a study by Gotoh and Asakawa showed that it was possible to induce PCC in G2-phase lymphocytes using the protein phosphatase inhibitor okadaic acid (Gotoh and Asakawa 1996). Later, other protein phosphatases were also applied (Durante et al. 1998), thereby significantly enhancing the suitability of the technique.

The PCC assay has also been applied for retrospective biodosimetry of astronauts, especially to compare results with those of metaphase analysis for complex chromosomal rearrangements. Some of these studies did not observe significant differences in the number of complex damages between pre- and post-flight samples (George et al. 2002; Greco et al. 2003) probably because exposures were too low. Another study evaluating translocations via the PCC assay did find increases in chromosome damage during flight, which was additive for repeated long-duration missions (George et al. 2013). In general, it is assumed that the PCC may be more accurate than metaphases for assessing complex chromosome damage because problems of chromosome damage underestimation due to cell cycle delays are avoided (George et al. 2002).

\subsubsection{Comet Assay (Single-Cell Gel Electrophoresis)}

The comet assay, also known as the single-cell gel electrophoresis assay, is a sensitive method for the detection of DNA damage and repair in individual cells (Singh et al. 1988). The size and shape of the comet and the distribution of DNA within the comet correlate with the extent of DNA damage (Fairbairn et al. 1995). For many years now, the comet assay has been utilized to study DNA damage induced by ionizing radiation. The dose range that can be investigated using the alkaline comet assay is $100 \mathrm{mGy}$ to $8 \mathrm{~Gy}$, although it has little potential as a radiation biodosimeter because of its lack of specificity for radiation-induced DNA damage (Pernot et al. 2012). However, this assay may be of interest because it can be used to evaluate DNA repair capacity which is a measure of individual radiosensitivity. A low DNA repair capacity is in general associated with increased (radiation-induced) cancer risk (Curtin 2012). 


\subsection{5 $\gamma$-H2AX Focus Assay}

Upon DNA DSB induction in mammals, the histone $\mathrm{H} 2 \mathrm{~A}$ variant $\mathrm{H} 2 \mathrm{AX}$ becomes rapidly phosphorylated at serine 139 in a region spanning several megabases around the initial lesion. The phosphorylated form of $\mathrm{H} 2 \mathrm{AX}$, termed $\gamma-\mathrm{H} 2 \mathrm{AX}$, facilitates the recruitment of other DNA repair factors to the damaged sites (Paull et al. 2000) and has an anchoring function to retain the broken chromosomal DNA ends in close proximity (Bassing and Alt 2004). As a result of the recruitment of DNA repair factors, a so-called focus is formed which can be easily visualized using light microscopy (Rogakou et al. 1999; Rogakou et al. 1998). As there is one focus formed per DSB, the number of DSBs can be directly determined from the number of foci that are present shortly after the induction of DNA damage.

The phosphorylation of H2AX occurs at a conserved carboxyl-terminal Ser-GInGlu (SQE) amino acid sequence and is catalyzed by members of the phosphoinositide 3-kinase (PI3K) family, such as DNA-PK catalytic subunit ATM, and ATR (Paull et al. 2000). The phosphorylation status of $\gamma-\mathrm{H} 2 \mathrm{AX}$ is under tight control of the kinase activity of the abovementioned protein kinases, as well as the phosphatase activity of protein phosphatases such as WIP1/PPM1D (Cha et al. 2010). Another way of removing $\gamma-\mathrm{H} 2 \mathrm{AX}$, after DNA damage has been repaired, is by histone exchange. It has also been shown that the mechanism of $\gamma$-H2AX phosphorylation is dependent on the type of genotoxic stress. For example, at the site of ionizing radiation-induced DSBs, the phosphorylation of $\mathrm{H} 2 \mathrm{AX}$ occurs mainly by ATM, whereas after UV irradiation the mechanism depends on the cell cycle and can occur in the absence of DSBs (Cha et al. 2010).

The $\gamma-\mathrm{H} 2 \mathrm{AX}$ assay is probably the most sensitive method to detect radiationinduced DNA damage. DSBs can be visualized in cells after exposures to doses as low as 2 mGy (Rothkamm and Lobrich 2003). However, it does suffer from a number of drawbacks, including a lack of specificity for radiation-induced damage and the transient nature of the signal (depending on the dose and radiation quality, DSBs are repaired within hours after exposure). This precludes its usefulness as a biomarker of exposure, but like the comet assay, it could be an excellent method to assess individual radiosensitivity based on DNA repair capacity measurements (Hall et al. 2017).

\subsection{Emerging Technologies for High-Throughput Screening}

As previously mentioned, classical cytogenetic measurements such as dicentrics and chromosomal translocations have been mostly used to detect chromosomal aberrations in peripheral blood lymphocytes of astronauts returning from longterm space missions (Beaton-Green et al. 2015; Cucinotta et al. 2008; Durante et al. 2003; Fedorenko et al. 2001; George et al. 2001, 2004, 2010, 2013; Obe et al. 1997; Testard et al. 1996; Yang et al. 1997). In the next paragraphs, we will review some emerging technologies which might be useful for high-throughput screening of interindividual differences in radiosensitivity. So far, these methods have not yet been used to evaluate radiation exposure or sensitivity in astronauts. 


\subsubsection{Transcriptomic Profiling}

Intrinsic radiosensitivity is correlated with the ability of the cell to detect and repair DNA damage (Hennequin et al. 2008), which is the ultimate factor for cell survival. To deal with radiation-induced DNA damage, cells have developed complex responses that rely on activation of genes that are involved in DNA damage repair and cell cycle arrest. However, when the cell damage is too severe, cellular apoptosis or cellular senescence can be induced, mainly via activation of p53 (Ou and Schumacher 2018), as a way to escape malignancy. Mechanistically, it is therefore likely that interindividual differences in DNA damage response gene activation may reflect individual radiation sensitivity. Thus, individuals having a genetic dysfunction of certain genes that are important for the DNA damage response display hypersensitivity toward ionizing radiation. In this context, not only the quality but also the quantity of changes in gene expression may differ greatly between individuals and contribute to the individual differences in response to radiation (Smirnov et al. 2009). For instance, in a screen of the radiation response between unrelated individuals and monozygotic twins it was shown that there was a very strong heritable component for the transcriptional response of the p53 target genes FDXR and $C D K N 1 A$ to ionizing radiation. The variability in their postirradiation expression levels was much smaller amongst the monozygotic twins than the unrelated individuals (Correa and Cheung 2004).

Since the early 2000's, many studies have demonstrated the usefulness of radiation-induced changes in gene expression as signatures that could be used for biodosimetry purposes [reviewed in Hall et al. (2017), Lacombe et al. (2018), and Pernot et al. (2012)]. With time and the development of new methods for gene expression profiling, these studies have shown an increasing sensitivity of gene signatures towards prediction of ever lower doses, down to $100 \mathrm{mGy}$ and below (Broustas et al. 2017; Knops et al. 2012; Macaeva et al. 2018; Macaeva et al. 2016; Nosel et al. 2013; Paul and Amundson 2011; Riecke et al. 2012), the dose range to which astronauts may be exposed. An important new application in this respect will be the identification of exon signatures, based on the observations of extensive radiation-induced alternative splicing (Macaeva et al. 2016; Sprung et al. 2011) which will benefit from advances in RNA sequencing methods. Another important finding from these studies is that these identified gene signatures are in general very robust, and independent of experimental conditions or differences related to the radiation itself (i.e., radiation quality, dose rate) (Hall et al. 2017). Finally, although most of these biomarkers have been investigated using ex vivo-irradiated blood samples, they have been proven to work also for in vivo-irradiated cancer patients (Abend et al. 2016; O'Brien et al. 2018; Paul and Amundson 2011). This is an important asset for their potential applicability for astronaut screening.

From these observations it can be concluded that the genes most appropriate for biodosimetry are those involved in the p53-regulated DNA damage response pathways. Interestingly, the same panel of genes has been proposed as potential biomarkers for studying radiation quality and dose rate effects, relevant for modeling cancer risk from space radiation (Sridharan et al. 2016). However, in contrast 
to gene expression signatures for individual radiosensitivity, genes that are useful for biodosimetry should ideally exhibit dose-dependent changes in expression with very little variation depending on age, gender, time, cell type, and/or other interindividual confounding factors (Pogosova-Agadjanyan et al. 2011).

\subsubsection{Epigenetic Profiling}

Besides individual differences in gene expression, differences in epigenetic marks may also influence the individual response to ionizing radiation. The term epigenetics has nowadays many different meanings. One classical definition is that epigenetics refers to changes in gene expression that do not involve changes in the DNA sequence but are nevertheless inherited (through mitosis and possibly meiosis) (Holliday 1987). Two classical epigenetic mechanisms are DNA methylation and posttranslational histone modification, both of which mainly affect gene expression by altering the chromatin structure, thereby making genes more or less accessible for transcription. Other epigenetic information carriers that have been proposed include transcription factors, prions, small RNAs (e.g., microRNAs), long intergenic noncoding RNAs and chromatin structure (Kaufman and Rando 2010; Rando 2016).

DNA methylation is a widely studied and best characterized epigenetic modification (Barros-Silva et al. 2018) and will therefore be mainly discussed here. It involves a covalent deposition of a methyl group, mostly catalyzed by DNA methyltransferases (DNMTs) at the 5' position of a cytosine ring, which occurs mostly in the vicinity of a CpG dinucleotide (Taby and Issa 2010). The $\mathrm{CpG}$ dinucleotides tend to cluster in so-called $\mathrm{CpG}$ islands which are often located in promoter regions of genes (about $60 \%$ of the human gene promoters are associated with $\mathrm{CpG}$ islands). In a normal differentiated cell, most promoter $\mathrm{CpG}$ islands are unmethylated whereas the $\mathrm{CpG}$ islands that are distributed across the genome-mostly associated with repetitive elements - are methylated. Methylation of CpG islands is generally associated with gene silencing via various mechanisms such as recruitment of methyl-CpG-binding domain proteins, recruitment of histone-modifying and chromatin-remodeling complexes, or by precluding the recruitment of DNA-binding proteins (e.g., transcription factors) to their target sites (Portela and Esteller 2010).

The first observation that radiation affects DNA methylation was reported in E. coli in 1972 (Whitfield and Billen 1972) while the first report in mammals suggested both hypo- and hypermethylation in Wistar and outbred rats exposed to high doses of $\gamma$-radiation (Rakova 1979). Following in vivo studies indicated that exposure to radiation induces in general a loss of global DNA methylation in hematopoietic tissues as well as liver, but not in muscle and lung (Miousse et al. 2017). Nevertheless, alterations in DNA methylation of specific genes in response to radiation exposure may go in both directions, and one gene often found to be hypermethylated, for instance in the sputum of uranium miners ( $\mathrm{Su}$ et al. 2006) or in lung-adenocarcinomas of Mayak nuclear facility workers (Belinsky et al. 2004) is the tumor-suppressor gene $C D K N 2 A$. 
Of relevance for space exploration are results from experimental animal studies, showing global DNA hypermethylation in lungs of C57BL6 mice after exposure to low absorbed doses of ${ }^{56} \mathrm{Fe}$ ions (Nzabarushimana et al. 2014), which was corroborated in a number of other studies demonstrating hypermethylation in repetitive elements in heart and lung of ${ }^{56} \mathrm{Fe}$-irradiated mice (Koturbash et al. 2016; Lima et al. 2014; Prior et al. 2016). Another study investigated the correlation between ${ }^{56} \mathrm{Fe}$-induced cognitive decline and changes in DNA methylation and hydroxymethylation (hmC) in the hippocampus, showing that especially hmC could be correlated to cognitive impairments (Impey et al. 2016). Interestingly, treatment of mice with the DNA methylation inhibitor 5-iodotubercidin partially restored DNA methylation levels and could improve cognitive function of mice exposed to a space-relevant dose of ${ }^{28}$ Si-ions (Acharya et al. 2017).

To link DNA methylation with other epigenetic markers, a recent study showed that the long noncoding RNA PARTICLE, which is specifically induced in response to low-dose radiation (O'Leary et al. 2015) links DNA and histone methylation and thereby affects gene expression at a genome-wide scale (O'Leary et al. 2017). Whether and how epigenetic mechanisms affect individual radiation sensititvity is currently under further investigation. In this respect, it is interesting to note that the NASA Twin Study, in which an astronaut spent 1 year at the ISS while his twin brother and fellow astronaut stayed on Earth, supposedly identified large changes in epigenetic modifications during spaceflight (Garrett-Bakelman et al. 2019).

\subsubsection{Multiple Protein Expression Profiling}

Although changes in gene transcription can serve as good candidate biomarkers, protein changes may be relevant as well (Hall et al. 2017). Differences in protein levels can occur between radioresistant and radiosensitive individuals, and therefore protein signatures might also have a predictive value (Chaze et al. 2013). Recent advances in proteomics might allow the identification of proteins associated with radiosensitivity (Leszczynski 2014; Smith et al. 2009; Turtoi et al. 2011).

\subsection{Conclusion}

For manned spaceflight, the biological effects induced by cosmic ray exposure on the immune and other organ systems are of critical concern to risk assessment for astronauts, especially since the orbiting (so-called (Deep Space) Gateway) and habitats on the moon are now clearly planned and envisaged for the near future. In this light, and when expanding further to the manned exploration of Mars, the increased risk of cancer associated with radiation exposure is widely considered to be the main obstacle to interplanetary travel (Chancellor et al. 2014; Cucinotta and Durante 2006; Durante and Cucinotta 2008). Shielding of the astronauts from space radiation is therefore a very important protective measure. Material shielding may only be partially effective against cosmic radiation in certain energy ranges, 
but may actually make the problem worse for some of the higher energy rays, as more shielding induces an increased amount of secondary radiation. Therefore, other protection measures such as onboard biodosimetry, or therapeutic measures, should also be considered, although their effectiveness in deep space is not yet established. Currently, several radioprotectors are available that can prevent and/ or reduce radiation-induced health effects by enhancing the body's natural capacity to repair cell damage caused by radiation or by preventing DNA damage to occur (McLaughlin et al. 2017; Smith et al. 2017). Another possible preventive measure could be to include the individual's radiation resistance to the induction of early and late radiation effects in the medical assessment of the mission crew applicants. This has to be complemented by the provision of adequate onboard biodosimetry tools to guarantee the best possible diagnostics and personalized care in-flight.

\section{References}

Abend M, Badie C, Quintens R, Kriehuber R, Manning G, Macaeva E, Njima M, Oskamp D, Strunz S, Moertl S, Doucha-Senf S, Dahlke S, Menzel J, Port M (2016) Examining radiationinduced in vivo and in vitro gene expression changes of the peripheral blood in different laboratories for biodosimetry purposes: first RENEB gene expression study. Radiat Res 185:109-123

Acharya MM, Baddour AA, Kawashita T, Allen BD, Syage AR, Nguyen TH, Yoon N, Giedzinski E, Yu L, Parihar VK, Baulch JE (2017) Epigenetic determinants of space radiation-induced cognitive dysfunction. Sci Rep 7:42885

Andreassen CN (2005) Can risk of radiotherapy-induced normal tissue complications be predicted from genetic profiles? Acta Oncol 44:801-815

Awa A (1997) Analysis of chromosome aberrations in atomic bomb survivors for dose assessment: studies at the radiation effects research foundation from 1968 to 1993. Stem Cells 15(Suppl 2):163-173

Barros-Silva D, Marques CJ, Henrique R, Jeronimo C (2018) Profiling DNA methylation based on next-generation sequencing approaches: new insights and clinical applications. Genes (Basel) 9:E429

Bassing CH, Alt FW (2004) H2AX may function as an anchor to hold broken chromosomal DNA ends in close proximity. Cell Cycle 3:149-153

Beaton-Green LA, Lachapelle S, Straube U, Wilkins RC (2015) Evolution of the Health Canada astronaut biodosimetry program with a view toward international harmonization. Mutat Res Genet Toxicol Environ Mutagen 793:101-106

Belinsky SA, Klinge DM, Liechty KC, March TH, Kang T, Gilliland FD, Sotnic N, Adamova G, Rusinova G, Telnov V (2004) Plutonium targets the p16 gene for inactivation by promoter hypermethylation in human lung adenocarcinoma. Carcinogenesis 25(6):1063-1067

Broustas CG, Xu Y, Harken AD, Chowdhury M, Garty G, Amundson SA (2017) Impact of neutron exposure on global gene expression in a human peripheral blood model. Radiat Res $187: 433-440$

Cha H, Lowe JM, Li H, Lee JS, Belova GI, Bulavin DV, Fornace AJ Jr (2010) Wip1 directly dephosphorylates gamma-H2AX and attenuates the DNA damage response. Cancer Res 70:4112-4122

Chancellor JC, Scott GB, Sutton JP (2014) Space radiation: the number one risk to astronaut health beyond low earth orbit. Life (Basel) 4:491-510

Chaze T, Hornez L, Chambon C, Haddad I, Vinh J, Peyrat JP, Benderitter M, Guipaud O (2013) Serum proteome analysis for profiling predictive protein markers associated with the severity of skin lesions induced by ionizing radiation. Proteomes 1:40-69 
Chistiakov DA, Voronova NV, Chistiakov PA (2008) Genetic variations in DNA repair genes, radiosensitivity to cancer and susceptibility to acute tissue reactions in radiotherapy-treated cancer patients. Acta Oncol 47:809-824

Correa CR, Cheung VG (2004) Genetic variation in radiation-induced expression phenotypes. Am J Hum Genet 75:885-890

Cologne JB, Pawel DJ, Preston DL (1998) Statistical issues in biological radiation dosimetry for risk assessment using stable chromosome aberrations. Health Phys 75:518-529

Cucinotta FA, Durante M (2006) Cancer risk from exposure to galactic cosmic rays: implications for space exploration by human beings. Lancet Oncol 7:431-435

Cucinotta FA, Kim MH, Willingham V, George KA (2008) Physical and biological organ dosimetry analysis for international space station astronauts. Radiat Res 170:127-138

Curtin NJ (2012) DNA repair dysregulation from cancer driver to therapeutic target. Nat Rev Cancer 12:801-817

Distel LV, Neubauer S, Keller U, Sprung CN, Sauer R, Grabenbauer GG (2006) Individual differences in chromosomal aberrations after in vitro irradiation of cells from healthy individuals, cancer and cancer susceptibility syndrome patients. Radiother Oncol 81:257-263

Durante M (2005) Biomarkers of space radiation risk. Radiat Res 164:467-473

Durante M, Cucinotta FA (2008) Heavy ion carcinogenesis and human space exploration. Nat Rev Cancer 8:465-472

Durante M, Furusawa Y, Gotoh E (1998) A simple method for simultaneous interphase-metaphase chromosome analysis in biodosimetry. Int J Radiat Biol 74:457-462

Durante M, Snigiryova G, Akaeva E, Bogomazova A, Druzhinin S, Fedorenko B, Greco O, Novitskaya N, Rubanovich A, Shevchenko V, Von Recklinghausen U, Obe G (2003) Chromosome aberration dosimetry in cosmonauts after single or multiple space flights. Cytogenet Genome Res 103:40-46

Fairbairn DW, Olive PL, O'Neill KL (1995) The comet assay: a comprehensive review. Mutat Res 339:37-59

Fedorenko B, Druzhinin S, Yudaeva L, Petrov V, Akatov Y, Snigiryova G, Novitskaya N, Shevchenko V, Rubanovich A (2001) Cytogenetic studies of blood lymphocytes from cosmonauts after long-term space flights on Mir station. Adv Space Res 27:355-359

Fenech M (2010) The lymphocyte cytokinesis-block micronucleus cytome assay and its application in radiation biodosimetry. Health Phys 98:234-243

Fenech M, Morley A (1985) Solutions to the kinetic problem in the micronucleus assay. Cytobios 43:233-246

Feng L, He L, Wang Y, Du L, Xu C, Liu Q, Fan F (2015) Eight-year follow-up study of three individuals accidentally exposed to (60)co radiation: chromosome aberration and micronucleus analysis. Mutat Res Genet Toxicol Environ Mutagen 784-785:10-14

Foray N, Bourguignon M, Hamada N (2016) Individual response to ionizing radiation. Mutat Res 770:369-386

Garrett-Bakelman FE (2019) The NASA Twins Study: A multidimensional analysis of a year-long human spaceflight. Science 12;364(6436)

George K, Durante M, Wu H, Willingham V, Badhwar G, Cucinotta FA (2001) Chromosome aberrations in the blood lymphocytes of astronauts after space flight. Radiat Res 156: $731-738$

George K, Wu H, Willingham V, Cucinotta FA (2002) Analysis of complex-type chromosome exchanges in astronauts' lymphocytes after space flight as a biomarker of high-LET exposure. J Radiat Res 43(Suppl):S129-S132

George K, Durante M, Willingham V, Cucinotta FA (2004) Chromosome aberrations of clonal origin are present in astronauts' blood lymphocytes. Cytogenet Genome Res 104:245-251

George K, Chappell LJ, Cucinotta FA (2010) Persistence of space radiation induced cytogenetic damage in the blood lymphocytes of astronauts. Mutat Res 701:75-79

George K, Rhone J, Beitman A, Cucinotta FA (2013) Cytogenetic damage in the blood lymphocytes of astronauts: effects of repeat long-duration space missions. Mutat Res 756: 165-169 
Gotoh E, Asakawa Y (1996) Detection and evaluation of chromosomal aberrations induced by high doses of gamma-irradiation using immunogold-silver painting of prematurely condensed chromosomes. Int J Radiat Biol 70:517-520

Greco O, Durante M, Gialanella G, Grossi G, Pugliese M, Scampoli P, Snigiryova G, Obe G (2003) Biological dosimetry in Russian and Italian astronauts. Adv Space Res 31:1495-1503

Hall J, Jeggo PA, West C, Gomolka M, Quintens R, Badie C, Laurent O, Aerts A, Anastasov N, Azimzadeh O, Azizova T, Baatout S, Baselet B, Benotmane MA, Blanchardon E, Gueguen Y, Haghdoost S, Harms-Ringhdahl M, Hess J, Kreuzer M, Laurier D, Macaeva E, Manning G, Pernot E, Ravanat JL, Sabatier L, Tack K, Tapio S, Zitzelsberger H, Cardis E (2017) Ionizing radiation biomarkers in epidemiological studies - an update. Mutat Res 771:59-84

Hennequin C, Quero L, Favaudon V (2008) Determinants and predictive factors of tumour radiosensitivity. Cancer Radiother 12:3-13

Holliday R (1987) The inheritance of epigenetic defects. Science 238:163-170

ICRP (2007) The 2007 recommendations of the International commission on radiological protection. ICRP publication 103. In Ann ICRP, 37

Impey S, Jopson T, Pelz C, Tafessu A, Fareh F, Zuloaga D, Marzulla T, Riparip LK, Stewart B, Rosi S, Turker MS, Raber J (2016) Short- and long-term effects of (56)Fe irradiation on cognition and hippocampal DNA methylation and gene expression. BMC Genomics 17:825

Kaufman PD, Rando OJ (2010) Chromatin as a potential carrier of heritable information. Curr Opin Cell Biol 22:284-290

Knops K, Boldt S, Wolkenhauer O, Kriehuber R (2012) Gene expression in low- and high-doseirradiated human peripheral blood lymphocytes: possible applications for biodosimetry. Radiat Res 178:304-312

Koturbash I, Miousse IR, Sridharan V, Nzabarushimana E, Skinner CM, Melnyk SB, Pavliv O, Hauer-Jensen M, Nelson GA, Boerma M (2016) Radiation-induced changes in DNA methylation of repetitive elements in the mouse heart. Mutat Res 787:43-53

Lacombe J, Sima C, Amundson SA, Zenhausern F (2018) Candidate gene biodosimetry markers of exposure to external ionizing radiation in human blood: a systematic review. PLoS One 13:e0198851

Leszczynski D (2014) Radiation proteomics: a brief overview. Proteomics 14:481-488

Lima F, Ding D, Goetz W, Yang AJ, Baulch JE (2014) High LET (56)Fe ion irradiation induces tissue-specific changes in DNA methylation in the mouse. Environ Mol Mutagen 55:266-277

Liu Q, Cao J, Wang ZQ, Bai YS, Lu YM, Huang QL, Zhao WZ, Li J, Jiang LP, Tang WS, Fu BH, Fan FY (2009) Dose estimation by chromosome aberration analysis and micronucleus assays in victims accidentally exposed to (60)co radiation. Br J Radiol 82:1027-1032

Macaeva E, Saeys Y, Tabury K, Janssen A, Michaux A, Benotmane MA, De Vos WH, Baatout S, Quintens R (2016) Radiation-induced alternative transcription and splicing events and their applicability to practical biodosimetry. Sci Rep 6:19251

Macaeva E, Mysara M, De Vos WH, Baatout S, Quintens R (2018) Gene expression-based biodosimetry for radiological incidents: assessment of dose and time after radiation exposure. Int $\mathrm{J}$ Radiat Biol 95(1):64-75

McLaughlin MF, Donoviel DB, Jones JA (2017) Novel indications for commonly used medications as radiation protectants in spaceflight. Aerosp Med Hum Perform 88:665-676

Miousse IR, Kutanzi KR, Koturbash I (2017) Effects of ionizing radiation on DNA methylation: from experimental biology to clinical applications. Int J Radiat Biol 93:457-469

Nosel I, Vaurijoux A, Barquinero JF, Gruel G (2013) Characterization of gene expression profiles at low and very low doses of ionizing radiation. DNA Repair (Amst) 12:508-517

Nzabarushimana E, Miousse IR, Shao L, Chang J, Allen AR, Turner J, Stewart B, Raber J, Koturbash I (2014) Long-term epigenetic effects of exposure to low doses of $56 \mathrm{Fe}$ in the mouse lung. J Radiat Res 55:823-828

Obe G, Johannes I, Johannes C, Hallman K, Reitz G, Facius R (1997) Chromosomal aberrations in blood lymphocytes of astronauts after long-term space flights. Int J Radiat Biol 72:727-734

O'Brien G, Cruz-Garcia L, Majewski M, Grepl J, Abend M, Port M, Tichy A, Sirak I, Malkova A, Donovan E, Gothard L, Boyle S, Somaiah N, Ainsbury E, Ponge L, Slosarek K, Miszczyk L, Widlak P, Green E, Patel N, Kudari M, Gleeson F, Vinnikov V, Starenkiy V, Artiukh S, Vasyliev L, Zaman A, Badie C (2018) FDXR is a biomarker of radiation exposure in vivo. Sci Rep 8:684 
O'Leary VB, Ovsepian SV, Carrascosa LG, Buske FA, Radulovic V, Niyazi M, Moertl S, Trau M, Atkinson MJ, Anastasov N (2015) PARTICLE, a triplex-forming long ncRNA, regulates locusspecific methylation in response to low-dose irradiation. Cell Rep 11:474-485

O'Leary VB, Hain S, Maugg D, Smida J, Azimzadeh O, Tapio S, Ovsepian SV, Atkinson MJ (2017) Long non-coding RNA PARTICLE bridges histone and DNA methylation. Sci Rep 7:1790

Ou HL, Schumacher B (2018) DNA damage responses and p53 in the aging process. Blood 131:488-495

Paul S, Amundson SA (2011) Gene expression signatures of radiation exposure in peripheral white blood cells of smokers and non-smokers. Int J Radiat Biol 87:791-801

Paull TT, Rogakou EP, Yamazaki V, Kirchgessner CU, Gellert M, Bonner WM (2000) A critical role for histone $\mathrm{H} 2 \mathrm{AX}$ in recruitment of repair factors to nuclear foci after DNA damage. Curr Biol 10:886-895

Pernot E, Hall J, Baatout S, Benotmane MA, Blanchardon E, Bouffler S, El Saghire H, Gomolka M, Guertler A, Harms-Ringdahl M, Jeggo P, Kreuzer M, Laurier D, Lindholm C, Mkacher R, Quintens R, Rothkamm K, Sabatier L, Tapio S, de Vathaire F, Cardis E (2012) Ionizing radiation biomarkers for potential use in epidemiological studies. Mutat Res 751:258-286

Pogosova-Agadjanyan EL, Fan W, Georges GE, Schwartz JL, Kepler CM, Lee H, Suchanek AL, Cronk MR, Brumbaugh A, Engel JH, Yukawa M, Zhao LP, Heimfeld S, Stirewalt DL (2011) Identification of radiation-induced expression changes in nonimmortalized human $\mathrm{T}$ cells. Radiat Res 175:172-184

Portela A, Esteller M (2010) Epigenetic modifications and human disease. Nat Biotechnol 28:1057-1068

Prior S, Miousse IR, Nzabarushimana E, Pathak R, Skinner C, Kutanzi KR, Allen AR, Raber J, Tackett AJ, Hauer-Jensen M, Nelson GA, Koturbash I (2016) Densely ionizing radiation affects DNA methylation of selective LINE-1 elements. Environ Res 150:470-481

Rakova IA (1979) Methylation of newly synthesized DNA in rat bone marrow and thymus after irradiation. Radiobiologiia 19:413-416

Rando OJ (2016) Intergenerational transfer of epigenetic information in sperm. Cold Spring Harb Perspect Med 6:a022988

Riecke A, Rufa CG, Cordes M, Hartmann J, Meineke V, Abend M (2012) Gene expression comparisons performed for biodosimetry purposes on in vitro peripheral blood cellular subsets and irradiated individuals. Radiat Res 178:234-243

Rodrigues AS, Oliveira NG, Gil OM, Leonard A, Rueff J (2005) Use of cytogenetic indicators in radiobiology. Radiat Prot Dosim 115:455-460

Rodrigues MA, Beaton-Green LA, Wilkins RC, Fenech MF (2018) The potential for complete automated scoring of the cytokinesis block micronucleus cytome assay using imaging flow cytometry. Mutat Res 836:53-64

Rogakou EP, Pilch DR, Orr AH, Ivanova VS, Bonner WM (1998) DNA double-stranded breaks induce histone H2AX phosphorylation on serine 139. J Biol Chem 273:5858-5868

Rogakou EP, Boon C, Redon C, Bonner WM (1999) Megabase chromatin domains involved in DNA double-strand breaks in vivo. J Cell Biol 146:905-916

Rothkamm K, Lobrich M (2003) Evidence for a lack of DNA double-strand break repair in human cells exposed to very low x-ray doses. Proc Natl Acad Sci U S A 100:5057-5062

Singh NP, McCoy MT, Tice RR, Schneider EL (1988) A simple technique for quantitation of low levels of DNA damage in individual cells. Exp Cell Res 175:184-191

Smirnov DA, Morley M, Shin E, Spielman RS, Cheung VG (2009) Genetic analysis of radiationinduced changes in human gene expression. Nature 459:587-591

Smith L, Qutob O, Watson MB, Beavis AW, Potts D, Welham KJ, Garimella V, Lind MJ, Drew PJ, Cawkwell L (2009) Proteomic identification of putative biomarkers of radiotherapy resistance: a possible role for the 26S proteasome? Neoplasia 11:1194-1207

Smith TA, Kirkpatrick DR, Smith S, Smith TK, Pearson T, Kailasam A, Herrmann KZ, Schubert J, Agrawal DK (2017) Radioprotective agents to prevent cellular damage due to ionizing radiation. J Transl Med 15:232

Sprung CN, Li J, Hovan D, McKay MJ, Forrester HB (2011) Alternative transcript initiation and splicing as a response to DNA damage. PLoS One 6:e25758 
Sridharan DM, Asaithamby A, Blattnig SR, Costes SV, Doetsch PW, Dynan WS, Hahnfeldt P, Hlatky L, Kidane Y, Kronenberg A, Naidu MD, Peterson LE, Plante I, Ponomarev AL, Saha J, Snijders AM, Srinivasan K, Tang J, Werner E, Pluth JM (2016) Evaluating biomarkers to model cancer risk post cosmic ray exposure. Life Sci Space Res (Amst) 9:19-47

Su S, Jin Y, Zhang W, Yang L, Shen Y, Cao Y, Tong J (2006) Aberrant promoter methylation of p16(INK4a) and $\mathrm{O}(6)$-methylguanine-DNA methyltransferase genes in workers at a Chinese uranium mine. J Occup Health 48:261-266

Suzuki M, Tsuruoka C, Nakano T, Ohno T, Furusawa Y, Okayasu R (2006) The PCC assay can be used to predict radiosensitivity in biopsy cultures irradiated with different types of radiation. Oncol Rep 16:1293-1299

Taby R, Issa JP (2010) Cancer epigenetics. CA Cancer J Clin 60:376-392

Taylor AM, Harnden DG, Arlett CF, Harcourt SA, Lehmann AR, Stevens S, Bridges BA (1975) Ataxia telangiectasia: a human mutation with abnormal radiation sensitivity. Nature 258:427-429

Testard I, Ricoul M, Hoffschir F, Flury-Herard A, Dutrillaux B, Fedorenko B, Gerasimenko V, Sabatier L (1996) Radiation-induced chromosome damage in astronauts' lymphocytes. Int J Radiat Biol 70:403-411

Thierens H, Vral A, Vandevoorde C, Vandersickel V, de Gelder V, Romm H, Oestreicher U, Rothkamm K, Barnard S, Ainsbury E, Sommer S, Beinke C, Wojcik A (2014) Is a semiautomated approach indicated in the application of the automated micronucleus assay for triage purposes? Radiat Prot Dosim 159:87-94

Tough IM, Buckton KE, Baikie AG, Court-Brown WM (1960) X-ray-induced chromosome damage in man. Lancet 2:849-851

Tucker JD (2008) Low-dose ionizing radiation and chromosome translocations: a review of the major considerations for human biological dosimetry. Mutat Res 659:211-220

Turtoi A, De Pauw E, Castronovo V (2011) Innovative proteomics for the discovery of systemically accessible cancer biomarkers suitable for imaging and targeted therapies. Am J Pathol 178:12-18

Varon R, Vissinga C, Platzer M, Cerosaletti KM, Chrzanowska KH, Saar K, Beckmann G, Seemanova E, Cooper PR, Nowak NJ, Stumm M, Weemaes CM, Gatti RA, Wilson RK, Digweed M, Rosenthal A, Sperling K, Concannon P, Reis A (1998) Nibrin, a novel DNA double-strand break repair protein, is mutated in Nijmegen breakage syndrome. Cell 93:467-476

Venkatesulu BP, Mallick S, Lin SH, Krishnan S (2018) A systematic review of the influence of radiation-induced lymphopenia on survival outcomes in solid tumors. Crit Rev Oncol Hematol 123:42-51

Vral A, Fenech M, Thierens H (2011) The micronucleus assay as a biological dosimeter of in vivo ionising radiation exposure. Mutagenesis 26:11-17

Wang ZZ, Li WJ, Zhang H, Yang JS, Qiu R, Wang X (2006) Comparison of clonogenic assay with premature chromosome condensation assay in prediction of human cell radiosensitivity. World J Gastroenterol 12:2601-2605

Whitfield BL, Billen D (1972) In vivo methylation of Escherichia coli DNA following ultraviolet and x-irradiation. J Mol Biol 63:363-372

Wojcik A, Bouffler S, Hauptmann M, Rajaraman P (2018) Considerations on the use of the terms radiosensitivity and radiosusceptibility. J Radiol Prot 38:N25-N29

Wu H, Hada M, Meador J, Hu X, Rusek A, Cucinotta FA (2006) Induction of micronuclei in human fibroblasts across the Bragg curve of energetic heavy ions. Radiat Res 166:583-589

Yang TC, George K, Johnson AS, Tavakoli A, Durante M, Fedorenko BS (1997) Cytogenetic effects of space radiation in lymphocytes of MIR-18 crews. Aviakosm Ekolog Med 31:8-14 
Open Access This chapter is licensed under the terms of the Creative Commons Attribution 4.0 International License (http://creativecommons.org/licenses/by/4.0/), which permits use, sharing, adaptation, distribution and reproduction in any medium or format, as long as you give appropriate credit to the original author(s) and the source, provide a link to the Creative Commons license and indicate if changes were made.

The images or other third party material in this chapter are included in the chapter's Creative Commons license, unless indicated otherwise in a credit line to the material. If material is not included in the chapter's Creative Commons license and your intended use is not permitted by statutory regulation or exceeds the permitted use, you will need to obtain permission directly from the copyright holder. 